\title{
Prevalence, antimicrobial resistance and staphylococcal toxin gene of blaTEM-1a-producing Staphylococcus aureus isolated from animals in Chongqing, China
}

\author{
Haoju Wang \\ Southwest University \\ Yao Chen \\ Southwest University \\ Xiaomei Jia \\ Southwest University \\ Honglei Ding ( $\nabla$ hongleiding@swu.edu.cn ) \\ Southwest University https://orcid.org/0000-0001-6978-0277
}

\section{Research article}

Keywords: Staphylococcus aureus; antimicrobial resistance; staphylococcal toxin gene; ESBL

Posted Date: August 6th, 2019

DOI: https://doi.org/10.21203/rs.2.12444/v1

License: () (i) This work is licensed under a Creative Commons Attribution 4.0 International License. Read Full License 


\section{Abstract}

Background Livestock-associated Staphylococcus aureus is one of the most important etiological agents in both human and animals. It has been reported with high antimicrobial resistance and multiple staphylococcal superantigen genes in many countries and several provinces of China. However, large-scale investigation of this organism has not been documented in Chongqing, China. The aim of this study is to demonstrate the prevalence, antimicrobial susceptibility and some molecular characteristics of S. aureus acquired from animals in Chongqing. Results A total of $89 \mathrm{~S}$. aureus isolates were cultured from 1371 samples picked up from March 2014 to December 2017. The isolates were originated from pigs (25), cattle (6), goats (10), rabbits (16) and chicken (32). Four MRSA strains were identified from 3 pig samples and 1 chicken sample. The isolates showed high resistance to penicillin (93.3\%) and ampicillin (92.1\%), but were more susceptible to amikacin and ofloxacin, since the resistance rates of these two drugs were less than $10 \%$. Meanwhile, $74.2 \%$ isolates exhibited varying degree of MDR. Almost all strains, except for 3 chicken-originated isolates, were positive for blaTEM-1a, but did not harbor other ESBL genes. Nineteen staphylococcal SE/SEI/TSST-1 genes, except seq, were detected in isolates. The predominant genes were sei (58.4\%), tst-1 (56.2\%) and seg (51.7\%). Conclusions The high antimicrobial resistance and prevalence of blaTEM-1a seriously reminded that it was urgent to standardize and cut down the usage of antimicrobials. The universal existence of staphylococcal toxin genes in isolated strains implied a potential threat of public health from animals to human through the food chain.

\section{Background}

Staphylococcus aureus (S. aureus) is a versatile opportunistic pathogen exiting widely in humans and food producing animals, such as pigs, poultry, ruminants and rabbits [1,2]. Many human diseases, ranging from superficial skin and soft tissue infection, pneumonia, septicemia, to endocarditis and other severe or even fatal diseases, are associated with S. aureus [3]. Some animal infectious diseases, such as mastitis, omphalitis, arthritis, septicemia, enteritis, are also mainly caused by $S$. aureus, and responsible for severe economic losses to animal husbandry [4-7].

S. aureus has the ability to gain antibiotic resistance determinants, and subsequently, displays resistance to corresponding antimicrobial agents and leads to the emergence of multi-drug resistant strains [8]. Methicillin-resistant $S$. aureus (MRSA) is $S$. aureus strain, that has mecA gene which encodes the penicillin-binding protein 2a (PBP2a), mediating resistance to methicillin and all other $\beta$-lactam antibiotics [9]. MRSA was initially discovered in an inpatient [10] and hospital-associated MRSA (HAMRSA) were considered as the main reservoir of this etiological agent [11]. Since 1990s, community-associated MRSA (CAMRSA) has been concerned as a serious health problem worldwide [11, 12]. In 1972, livestock-associated MRSA (LA-MRSA) was first discovered from mastitic cows [13]. Since then, the prevalence of LA-MRSA has been concerned and detected by many scientists in different animals and countries [1,14-17]. Human infection might be transmitted from pig-associated MRSA, such as ST398 [18]. This indicated that pigs were important reservoir for human-infected MRSA. Recent studies also found that MRSA ST398 could be isolated from other animals, such as goats [19], rabbits [20], and cattle [21], etc. In addition, methicillinsusceptible $S$. aureus (MSSA) isolated from both human and animals also exhibited multi-drug resistance (MDR) to various classes of antimicrobials [22, 23].

Extended spectrum $\beta$-lactamases (ESBLs) are a class of enzymes produced usually by Gram-negative bacteria, especially in enterobacteriaceae and Pseudomonas aeruginosa, that are able to hydrolyze extended spectrum cephalosporin and aztreonam while being inhibited by $\beta$-lactamase inhibitors, like clavulanic acid and tazobactam [24]. ESBLs have spread threateningly in many regions of the world in human beings and many species of animals [24,25]. To date, no ESBL gene identified from $S$. aureus has been reported. Additionally, most of $S$. aureus produce a variety of superantigens, including staphylococcal enterotoxins (SES), SE-like toxins (SEls) and toxic shock syndrome toxin 1 (TSST-1) [26]. These toxins are the causes of food poisoning resulting from the consumption of $S$. aureus contaminated food, such as milk and chicken $[27,28]$.

Although there have been a great deal of reports on the epidemiological studies of $S$. aureus originated from food producing animals in China in recent years [1,29,30], little is known about the prevalence and occurrence of this organism in Chongqing, China. In this study, we investigated the prevalence of $S$. aureus isolated from food animals in Chongqing. Furthermore, antimicrobial susceptibility, MRSA strains, ESBL genes and staphylococcal toxin genes were also characterized.

Page 2/15 


\section{Results}

\section{Prevalence of $S$. aureus from animals}

A total of 89 S. aureus isolates were recovered from 1371 samples during March 2014 and December 2017 in Chongqing, and the overall prevalence was $6.5 \%$ (Table 1 ). The isolation frequency varied in different animals. Of these, $25(7.3 \%)$ were isolated from 343 pig samples, 1 (0.6\%) were isolated from 165 beef cattle samples, 5 (2.6\%) were isolated from 190 dairy cattle samples, 10 (11.4\%) were isolated from 88 goat samples, 16 (15.2\%) were obtained from 105 rabbit samples, and 32 (6.7\%) were obtained from 480 chicken samples. The prevalence rate of $S$. aureus among rabbits was the highest. However, the prevalence rate in cattle was low, and the rate in beef cattle was the lowest and no more than $1 \%$.

Four strains carrying mecA gene were classified as MRSA and the prevalence was $0.3 \%$ from samples. The positive rate of MRSA in S. aureus isolates was 4.5\%. Three MRSA were pig-originated and all these strains were obtained from the same farm. The prevalence of MRSA in pigs was $0.9 \%$ and the rate in pig-associated isolates was $12.0 \%$. Additionally, 1 was isolated from a chicken farm. Therefore, the prevalence of MRSA in chicken was $0.2 \%$ and the rate in chicken-associated isolates was $3.1 \%$. The MRSA isolation rate was higher in pigs than that in chicken. Conversely, MRSA was not detected in other animal samples.

\section{Susceptibility of $S$. aureus to antimicrobials}

The result of the antimicrobial susceptibility of all $89 \mathrm{~S}$. aureus isolates were summarized in Table 2. Overall, $S$. aureus isolates showed high resistance rates against multiple antimicrobials, including penicillin (93.3\%, 83/89), ampicillin (92.1\%, 82/89), followed by tetracycline $(57.3 \%, 51 / 89)$, cefazolin $(47.2 \%, 42 / 89)$, doxycycline $(44.9 \%, 40 / 89)$, erythromycin $(41.6 \%, 37 / 89)$, azithromycin (40.4\%, 36/89), clarithromycin (38.3\%, 35/89), clindamycin (38.2\%, 34/89), kanamycin $(34.8 \%, 31 / 89)$, chloramphenicol $(31.5 \%, 28 / 89)$, tobramycin $(30.3 \%, 27 / 89)$. Moderate resistance can be found from ciprofloxacin $(29.2 \%$, $26 / 89)$, cefoxitin $(28.1 \%, 25 / 89)$, trimethoprim $(28.1 \%, 25 / 89)$, norfloxacin $(27.0 \%, 24 / 89)$, enrofloxacin $(27.0 \%, 24 / 89)$, enoxacin $(25.8 \%, 23 / 89)$ and trimethoprim-sulfamethoxazole $(20.2 \%, 18 / 89)$. On the contrary, the isolates indicated significantly low resistance to amikacin $(4.5 \%, 4 / 89)$, ofloxacin $(9.0 \%, 8 / 89)$, cephalothin $(10.1 \%, 9 / 89)$, gentamicin $(12.4 \%, 11 / 89)$ and imipenem $(15.7 \%, 14 / 89)$.

All pig-associated isolates showed resistance to penicillin and ampicillin, and majority of them was resistant to azithromycin $(60.0 \%, 15 / 25)$, doxycycline $(60.0 \%, 15 / 25)$, clindamycin $(60.0 \%, 15 / 25)$, erythromycin $(56.0 \%, 14 / 25)$, tetracycline $(56.0 \%$, 14/25), chloramphenicol $(52.0 \%, 13 / 25)$, norfloxacin $(52.0 \%, 13 / 25)$, enrofloxacin $(52.0 \%, 13 / 25)$ and trimethoprim $(52.0 \%$, $13 / 25)$. Meanwhile, most of them were susceptible or intermediately susceptible to amikacin $(100.0 \%, 25 / 25)$ and cephalothin $(96.0 \%, 24 / 25)$. All cattle-associated isolates showed resistance to penicillin, ampicillin, and susceptibility or intermediate susceptibility to cefoxitin, amikacin, ofloxacin, cephalothin, gentamicin, chloramphenicol, enrofloxacin and cefazolin. Meanwhile, most isolates were susceptible to other antimicrobials. All goat-associated isolates showed resistance to penicillin and ampicillin and (intermediate) susceptibility to cefoxitin, imipenem, enoxacin, gentamicin, clindamycin, norfloxacin, enrofloxacin, enoxacin, and trimethprim-sulfamethoxazole. More than $80 \%$ isolates were (intermediately) susceptible to cephalothin, amikacin, clarithromycin, chloramphenical, ciprofloxacin, ofloxacin and trimethoprim. All rabbit-associated isolates were susceptible or intermediately susceptible to 4 tested aminoglycosides (kanamycin, gentamicin, amikacin and tobramycin), 5 fluoroquinolones (norfloxacin, ciprofloxacin, enrofloxacin, ofloxacin, enoxacin), chloramphenicol and doxycycline. Most strains were (intermediate) susceptibility to azithromycin $(81.3 \%, 13 / 16)$, trimethoprim-sulfamethoxazole $(87.5 \%, 14 / 16)$ and trimethoprim $(81.3 \%, 13 / 16)$. Nevertheless, more than half of them were resistant to penicillin $(62.5 \%, 10 / 16)$ and ampicillin $(62.5 \%, 10 / 16)$. All chicken-associated isolates showed resistance to penicillin and more than half of them was resistant to ampicillin $(96.9 \%, 31 / 32)$, tetracycline $(65.6 \%, 21 / 32)$, doxycycline $(59.4 \%, 19 / 32)$ and cefazolin $(53.1 \%, 17 / 32)$. Meanwhile, most of them were more (intermediately) susceptible to cephalothin $(93.8 \%, 30 / 32)$, imipenem $(90.6 \%, 29 / 32)$, gentamicin $(90.6 \%, 29 / 32)$, amikacin $(90.6 \%, 29 / 32)$, ofloxacin $(90.6 \%, 29 / 32)$ and trimethoprim-sulfamethoxazole $(87.5 \%, 28 / 32)$.

All MRSA strains were resistant to penicillin, ampicillin, erythromycin, azithromycin, clarithromycin, tetracycline, doxycycline, chloramphenicol, clindamycin, trimethoprim-sulfamethoxazole and trimethoprim. Three pig-associated MRSA indicated 
resistance to kanamycin, tobramycin, norfloxacin, ciprofloxacin, enrofloxacin and enoxacin (Table S2).

Among the 89 organisms, 66 (74.2\%) isolates exhibited varying degree of MDR. The S. aureus isolates that exhibited MDR were composed of 19 (76.0\%) strains from pigs, 3 (50.0\%) strains from cattle, 7 (70.0\%) strains from goats, 10 (62.5\%) strains from rabbits, and 27 (84.4\%) strains from chicken. Notably, the isolates (80.7\%) from pigs and chicken exhibited substantially higher MDR rate than those (62.5\%) from herbivores. Twenty-two (24.7\%) isolates were resistant to 7 or more chasses of antimicrobials; among them, 13 were isolated from pigs and 9 were acquired from chicken, the ratios in their total quantities were $52.0 \%$ and $28.1 \%$, respectively. Three isolates from pigs were found to be resistance to 10 classes of drugs.

Four MRSA strains had high MDR. The chicken-associated MRSA was resistant to 8 classes of drugs. However, 2 pig-associated isolates were resistant to 9 , and 1 was resistant to 10 classes of antimicrobials.

\section{Prevalence of ESBL genes}

In all, $86(96.6 \%)$ isolates harbored bla $a_{\mathrm{TEM}}$ genes with the exception of 3 chicken-associated strains, and all b/a $a_{\mathrm{TEM}}$ belonged to TEM-1a. No other ESBL gene was detected with listed primers in Table S1. Interestingly, 1 MRSA strain isolated from chicken sample did not contain bla TEM gene.

\section{Profile of staphylococcal SE/SEI/TSST-1 genes}

A total of 20 staphylococcal toxin genes were amplified in $S$. aureus isolates. The results were shown in Table 4, Table S3 and Fig. 1. Nineteen genes, except seq, were detected in this study. The most prevalent gene was sei $(52,58.4 \%)$, followed by $t s t-1$ (50,56.2\%), seg (46, 51.7\%), selj (35, 39.3\%), seo (34,38.2\%), sem (32,36.0\%), sek (29, 32.6\%), sel (24, 27.0\%), sec (21, 23.4\%) and $\operatorname{sen}(19,21.3 \%)$. The prevalence rates of 5 genes were between $10 \%$ and $20 \%$, namely, seh $(13,14.6 \%)$, ser $(12,13.5 \%)$, ses $(11,12.4 \%)$, set $(10,11.2 \%)$ and sed $(9,10.1 \%)$. However, sea and seb were amplified from $4(4.5 \%)$ and $5(5.6 \%)$ strains, respectively. Only 1 strain obtained from dairy cattle was positive for gene see.

The toxin patterns were variable, from 1 to 10 except for one rabbit-associated strain that no toxin gene was amplified (Table 5, Table S3). Four isolates only had 1 gene. More than 1 gene were detect in 8, 13, 18, 12, 9, 15 and 5 isolates, and they were positive for 2, 3, 4, 5, 6, 7 and 8 toxin genes. Two pig-associated isolates and 1 rabbit-associated isolate harbored 9 toxin genes. Ten toxin genes were observed from 1 strain isolated from a pig.

\section{Discussion}

In this study, we investigated the prevalence of $S$. aureus in different food producing animals, including pigs, cattle, goats, rabbits and chicken, in Chongqing, China. To our understanding, this is the first comprehensive survey on livestock-associated $S$. aureus in Chongqing, although numerous epidemiological studies of this organism have been carried out in other regions of China [1, 29, 30], and a report about $S$. aureus isolated from goats in Chongqing [31] has been published. The average prevalence of $S$. aureus in our study was similar with those obtained from Jiangmen, China [30], but differed from other areas. For instance, a study carried out in Henan showed that $23.7 \%$ of animal samples collected from cows, swine, chicken and ducks, were positive for $S$. aureu [1]. Dan M et al. showed that a high isolation rate of $S$. aureus (46.0\%) was obtained from cattle farms in Xinjiang Province, China [29]. A longitudinal study in Ireland indicated the average prevalence of $S$. aureus colonization in pigs varied between $26 \%$ and $73 \%$ [32]. The study [31] carried out in Chongqing indicated that the prevalence (46\%) of goatassociated $S$. aureus was higher than isolation rate $(11.4 \%)$ of $S$. aureus obtained from goats in our study. The differences of isolation rates can be interpreted because of the culture media and methods, samples types, different regions, animal species, farm hygienic conditions, and so on. In our study, the isolation rate varied significantly between different animals, from $0.6 \%$ of beef cattle samples to $15.2 \%$ of rabbit samples.

In the present study, 4 MRSA were isolated from 3 pig samples and 1 chicken sample, but not other animals. The prevalence of MRSA in our studywas lower than most researches, both in China [1, 29, 33] and foreign countries [14, 34]. However, the study 
developed in Chongqing did not detect mecA gene in all 32 identified goat-originated $S$. aureus [31]. This study was identical to our result about the goat-associated isolates. Although the prevalence of MRSA was at a low level, the resistance of $S$. aureus isolates to penicillins was serious. Therefore, LA-MRSA might become very popular and the prevalence rate might be much higher in animals in the future under the selective pressure of $\beta$-lactam antibacterial drugs. As the LA-MRSA is a reservoir of health-threatening organism for people [19-21,33], longitudinal surveillance of MRSA in animals, especially in pigs and chicken, should be performed periodically.

Most of isolates, particularly obtained from pigs and chicken, in this study, were high resistance and multi-drug resistant. The high prevalence of resistance to antimicrobials in our study was similar to that reported in previous studies $[1,29,33,35]$. Antimicrobial agents are often used for the prevention and treatment of infectious diseases and growing promotion of food producing animals in intensive production. Based on records of antimicrobial usage at each farm, overuse of antimicrobials is the possible explanation of extensive drug resistance. The isolates were most resistant to penicillins, but seemed susceptible to amikacin, ofloxacin, cephalothin, gentamicin and imipenem. On the other hand, most antimicrobials showed less resistance in herbivores than in pigs and chicken. The trend was also observed in MDR strains in different animals. For example, the ratio of MDR isolates obtained from pigs and chicken was higher than herbivore-originated strains. This might be related to the more frequencies of bacterial infectious diseases, thereby leading to more usage of antimicrobials, in pigs and chicken than in herbivores. More importantly, some isolates were resistant to animal-prohibited antimicrobials, such as imipenem, clarithromycin, chloramphenicol, clindamycin and enoxacin, for the selective pressure from the corresponding same class of antimicrobials, which were widely used in animal production. For example, florfenicol was applied in veterinary infectious disease treatment universally. Although chloramphenicol was inhibited in application on animal diseases, the resistance rate was $31.5 \%$ in our study. The reason might be that chloramphenicol and florfenicol were both resistant to the productions of chloramphenicol/florfenicol exporter genes [36].

We found a great proportion of isolates were resistant to cephalosporins. This suggested that these strains have one or more ESBL genes, although no similar assay has been reported. In this study, we discovered that almost all strains, except for 3 chicken-originated isolates, were positive for b/a $a_{\mathrm{TEM}-1 \mathrm{a}}$, but did not harbor other ESBL genes, even though more than one pair primers published in articles were attempted (Data not shown). In the further study, we will isolate more $S$. aureus clinical strains and try to find more ESBL genes. Meanwhile, we will explore the conjugation machanism of TEM-1a gene from Enterobacteriaceae to $S$. aureus and from $S$. aureus to $S$. aureus.

The prevalence of staphylococcal toxin genes in this study was different from other reports. The prevailing toxin genes was sei (56.2\%), tst-1 (56.2\%) and seg (51.7\%), which were more than $50 \%$ in isolated strains, followed by selj (35, 39.3\%), seo (34, $38.2 \%$ ) and $\operatorname{sem}(32,36.0 \%)$, that the prevalence was between $30 \%$ and $60 \%$. The SE genes, sea and seb, existed only in 4 and 5 strains, respectively. The most predominant toxin genes were sed $(20.28 \%)$, selj (20.98\%) and set (37.76\%) in the report from Liu et al. [1]. Dan et al. showed that sea, seb and sec were more prevalent in S. aureus isolated from Xinjiang [29] than in our study. The detection rates of sea to selj and tst-1 performed in goat-associated S.aureus isolated from Chongqing [31] were very different from our result. The reason might be different sampling time and different counties. However, some studies reported that sec gene was the most prevalent and widespread in SEs [34, 37, 38], especially in Europe [34, 37, 38]. Though we did not detect sep gene, it could be found in other provinces in China [1,39, 40], ever much higher.

\section{Conclusions}

In conclusion, this was the first investigation of prevalence, antimicrobial susceptibility and molecular characterization of S.aureus isolates from food producing animals in Chongqing. The high antimicrobial resistance and prevalence of $b / a_{T E M}-1 a$ seriously reminded that it was urgent to standardize the use of antimicrobials. Meanwhile, optimization of management practices and housing conditions should be applied to animals, such that reduction of veterinary infectious diseases in herds will be effective and the usage of antimicrobials can be cut down. The universal existence of staphylococcal SE/SEI/TSST-1 genes in isolated strains implied a risk of staphylococcal food poisoning that livestock-associated $S$. aureus were transmitted from animals to human through the food chain. 


\section{Methods}

\section{Samples collection}

From March 2014 to December 2017, a total of 1371 samples were collected from healthy animals in Chongqing, China. Samples were collected in a random manner from pigs $(n=343)$ and rabbits $(n=105)$ by nasal swabs, beef cattle $(n=165)$ and goats $(n=88)$ by feces, chicken $(n=480)$ by anal swabs, and dairy cattle $(n=190)$ by milk. The farmers of each farm gave permission for sample collection. The animal did not suffer from any diseases and administer any drugs. All samples were stored in low temperature with ice and were taken back to laboratory within $6 \mathrm{~h}$.

\section{Isolation and identification of $S$. aureus}

Isolation and identification of $S$. aureus were performed after the samples arrived at laboratory immediately. Briefly, each fecal sample was mixed with $2 \mathrm{~mL}$ PBS for $2 \mathrm{~h}$ in order to release bacteria. About $0.2 \mathrm{~mL}$ milk or PBS mixture was added to $10 \mathrm{~mL}$ Mueller-Hinton broth containing $10 \% \mathrm{NaCl}$ and cultured at $37^{\circ} \mathrm{C}$ for $10 \mathrm{~h}$. The medium was streaked onto mannitol salt plate and incubated at $37^{\circ} \mathrm{C}$ for $20 \mathrm{~h}$. Presumptive colonies were transferred into Luria-Bertani medium for enrichment at $37^{\circ} \mathrm{C}$ for $8 \mathrm{~h}$ on a rotary incubator. DNA was extracted from culture, and $S$. aureus isolate was confirmed by amplifying its specific gene nuc. The primers and annealing temperature were listed in Table S1. S. aureus ATCC 25923 was used as positive control. All confirmed $S$. aureus clinical strains were cultured in Luria-Bertani medium until reached to exponential grown phase and stored with $40 \%$ glycerol at $-80^{\circ} \mathrm{C}$.

\section{Bacterial DNA extraction}

Culture was centrifuged at $5000 \mathrm{r} / \mathrm{min}$ for $5 \mathrm{~min}$, and the pellet was resuspended in $1 \mathrm{~mL}$ sterile water. Suspension was centrifuged and the supernatant was discarded. The pellet resuspended with $0.1 \mathrm{~mL}$ sterile water was treated in a thermostat at $105^{\circ} \mathrm{C}$ for $10 \mathrm{~min}$ and immediately frozen at $-20^{\circ} \mathrm{C}$ for $30 \mathrm{~min}$ three times, followed by centrifugation at $10000 \mathrm{r} / \mathrm{min}$ for 10 min. The supernatant was removed without disturbing the pellet and the extracted genomic DNA was stored at $-20^{\circ} \mathrm{C}$ as the template for PCR.

\section{Antimicrobial susceptibility testing}

Antimicrobial susceptibility of all $S$. aureus isolates were performed by disk diffusion method on Mueller-Hinton agar plates and interpreted according to the Clinical and Laboratory Standards Institute guidelines VET01-S4 [41] and M100-S25 [42]. The antimicrobials included penicillin (10 units), ampicillin $(10 \mu \mathrm{g})$, cephalothin $(30 \mu \mathrm{g})$, cefazolin $(30 \mu \mathrm{g})$, cefoxitin $(30 \mu \mathrm{g})$, imipenem $(10 \mu \mathrm{g})$, kanamycin $(30 \mu \mathrm{g})$, gentamicin $(30 \mu \mathrm{g})$, amikacin $(30 \mu \mathrm{g})$, tobramycin $(10 \mu \mathrm{g})$, erythromycin $(15 \mu \mathrm{g})$, azithromycin $(15 \mu \mathrm{g})$, clarithromycin $(15 \mu \mathrm{g})$, tetracycline $(30 \mu \mathrm{g})$, doxycycline $(30 \mu \mathrm{g})$, chloramphenicol $(30 \mu \mathrm{g})$, clindamycin $(2$ $\mu \mathrm{g})$, norfloxacin $(10 \mu \mathrm{g})$, ciprofloxacin $(5 \mu \mathrm{g})$, enrofloxacin $(5 \mu \mathrm{g})$, ofloxacin $(5 \mu \mathrm{g})$, enoxacin $(10 \mu \mathrm{g})$, trimethoprimsulfamethoxazole $(1.25 / 23.75 \mu \mathrm{g})$ and trimethoprim $(5 \mu \mathrm{g})$. S. aureus ATCC 25923, Escherichia coli ATCC 25922 were used as quality control strains. MDR was defined as resistance to at least three or more different classes of antimicrobials.

\section{Detection of mecA and ESBL genes, and nucleotide sequencing}

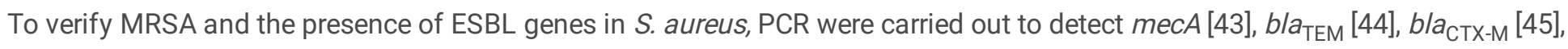
$b / a_{\mathrm{SHV}}[46], b / a_{\mathrm{OXA}-1}$ [47], b/a $a_{\mathrm{OXA}-2}$ [47], b/a $a_{\mathrm{OXA}-10}$ [47], b/a $a_{\mathrm{PSE}}$ [48], b/a $a_{\mathrm{PER}}[48], b / a_{\mathrm{GES}}[49]$ and $b / a_{\mathrm{VEB}}$ [49] genes. Primers and related parameters were summarized in Table S1. The amplified products of ESBL genes were sequenced from both directions by BGI company. Nucleotide sequences were analyzed by searching GenBank using BLAST

(http://www.ncbi.nlm.nih.gov/blast/). 


\section{Determination of SE/SEI/TSST-1 genes}

The presence of SE, SEl and TSST-1 genes was confirmed by PCR using specific primers described in Table S1. Twenty genes were determined using amplification conditions described in corresponding literatures [50-54].

\section{Abbreviations}

ESBL: extended-spectrum $\beta$-lactamases; MRSA: methicillin-resistant Staphylococcus aureus; SEs: staphylococcal enterotoxins; SEls: SE-like toxins; TSST-1: toxic shock syndrome toxin-1.

\section{Declarations}

\section{Ethics approval and consent to participate}

This study was performed in accordance with the recommendations in the Guide for the Care and Use of Laboratory Animals of the Ministry of Health, China. All experimental protocols were approved by the Institutional Animal Ethics Committee of Southwest University and performed accordingly.

\section{Consent for publication}

Not applicable.

\section{Availability of data and materials}

All data generated or analysed during this study are included in this published article and its supplementary information files.

\section{Competing interests}

The authors declare that they have no competing interests.

\section{Funding}

This work was supported by National Key R\&D Program of China (2018YFD0500305), Technological Innovation and Application Demonstration Project of Chongqing (cstc2018jscx-mszdX0076) and Fundamental Research Funds for the Central Universities (XDJK2019F001).

\section{Authors' contributions}

HD conceived and designed the study and analyzed the data. HW, YC and XJ performed the experiments, interpreted the results. HD wrote the manuscript. All authors reviewed the results and approved the final version of manuscript.

\section{Acknowledgements}

The authors would like to thank Qingke Kong and Yuanxiao Li for their writing assistance of the manuscript.

\section{References}


1. Liu B, Sun H, Pan Y, Zhai Y, Cai T, Yuan X, Gao Y, He D, Liu J, Yuan L, Hu G. Prevalence, resistance pattern, and molecular characterization of Staphylococcus aureus isolates from healthy animals and sick populations in Henan Province, China. Gut Pathog. 2018; 10, 31.

2. Portillo BC, Moreno JE, Yomayusa N, Alvarez CA, Cardozo BE, Pérez JA, Díaz PL, Ibañez M, Mendez-Alvarez S, Leal AL, Gómez NV. Molecular epidemiology and characterization of virulence genes of community-acquired and hospital-acquired methicillin-resistant Staphylococcus aureus isolates in Colombia. Int J Infect Dis. 2013; 17(9), e744-9.

3. David MZ, Daum RS. Treatment of Staphylococcus aureus infections. Curr Top Microbiol Immunol. 2017; 409, 325-83.

4. Iwata K, Doi A, Fukuchi T, Ohji G, Shirota Y, Sakai T, Kagawa H. A systematic review for pursuing the presence of antibiotic associated enterocolitis caused by methicillin resistant Staphylococcus aureus. BMC Infect Dis. 2014; 14, 247.

5. Kim CK, Karau MJ, Greenwood-Quaintance KE, Tilahun AY, David CS, Mandrekar JN, Patel R, Rajagopalan G. Superantigens in Staphylococcus aureus isolated from prosthetic joint infection. Diagn Microbiol Infect Dis. 2015; 81(3), 201-7.

6. Li J, Jiang N, Ke Y, Feßler AT, Wang Y, Schwarz S, Wu C. Characterization of pig-associated methicillin-resistant Staphylococcus aureus. Vet Microbiol. 2017; 201, 183-7.

7. Terzolo HR, Shimizu A. Biological characters and bacteriophage typing of Staphylococcus aureus isolated from chicken staphylococcosis and commercial balanced chicken food in Argentine. Rev Argent Microbiol. 1979; 11(3), 89-101.

8. Rybak MJ, LaPlante KL. Community-associated methicillin-resistant Staphylococcus aureus: a review. Pharmacotherapy. $2005 ; 25(1), 74-85$.

9. Fishovitz J, Hermoso JA, Chang M, Mobashery S. Penicillin-binding protein 2a of methicillin-resistant Staphylococcus aureus. IUBMB Life. 2014; 66(8), 572-7.

10. Eriksen KR. “Celbenin”-resistant staphylococci. Ugeskr Laeger. 1961; 123, 384-6.

11. Deurenberg RH, Stobberingh EE. The molecular evolution of hospital- and community-associated methicillin-resistant Staphylococcus aureus. Curr Mol Med. 2009; 9(2), 100-15.

12. DeLeo FR, Otto M, Kreiswirth BN, Chambers HF. Community-associated meticillin-resistant Staphylococcus aureus. Lancet. 2010; 375(9743), 1557-68.

13. Devriese LA, Van Damme LR, Fameree L. Methicillin (cloxacillin)-resistant Staphylococcus aureus strains isolated from bovine mastitis cases. Zentralbl Veterinarmed B. 1972; 19(7), 598-605.

14. Aires-de-Sousa M. Methicillin-resistant Staphylococcus aureus among animals: current overview. Clin Microbiol Infect. 2017; 23(6), 373-80.

15. Hanley PW, Barnhart KF, Abee CR, Lambeth SP, Weese JS. Methicillin-resistant Staphylococcus aureus prevalence among captive chimpanzees, Texas, USA, 2012(1). Emerg Infect Dis. 2015; 21(12), 2158-60.

16. Monaco M, Pedroni P, Sanchini A, Bonomini A, Indelicato A, Pantosti A. Livestock-associated methicillin-resistant Staphylococcus aureus responsible for human colonization and infection in an area of Italy with high density of pig farming. BMC Infect Dis. 2013; 13, 258.

17. Siiriken B, Yildirim T, Güney AK, Erol I, Durupinar B. Prevalence and molecular characterization of methicillin-resistant Staphylococcus aureus in foods of animal origin, Turkey. J Food Prot. 2016; 79(11), 1990-4.

18. Huss A, Wannet WJ, de Neeling AJ. Community-acquired MRSA and pig-farming. Ann Clin Miijsdens XW, van Dijke BJ, Spalburg E, van Santen-Verheuvel MG, Heck ME, Pluister GN, Vocrobiol Antimicrob. 2006; 5, 26.

19. Loncaric I, Brunthaler R, Spergser J. Suspected goat-to-human transmission of methicillin-resistant Staphylococcus aureus sequence type 398. J Clin Microbiol. 2013; 51(5), 1625-6.

20. Loncaric I, Künzel F. Sequence type 398 meticillin-resistant Staphylococcus aureus infection in a pet rabbit. Vet Dermatol. 2013; 24(3), 370-2.

21. Fessler AT, Kadlec K, Schwarz S. Novel apramycin resistance gene apmA in bovine and porcine methicillin-resistant Staphylococcus aureus ST398 isolates. Antimicrob Agents Chemother. 2011; 55(1), 373-5.

22. Chao G, Zhang X, Zhang X, Huang Y, Xu L, Zhou L, Yang W, Jiang Y, Xue F, Wu Y. Phenotypic and genotypic characterization of methicillin-resistant Staphylococcus aureus (MRSA) and methicillin-susceptible Staphylococcus aureus (MSSA) from 
different sources in China. Foodborne Pathog Dis. 2013; 10(3), 214-21.

23. Vandendriessche S, Vanderhaeghen W, Larsen J, de Mendonça R, Hallin M, Butaye P, Hermans K, Haesebrouck F, Denis 0. High genetic diversity of methicillin-susceptible Staphylococcus aureus (MSSA) from humans and animals on livestock farms and presence of SCCmec remnant DNA in MSSA CC398. J Antimicrob Chemother. 2014; 69(2), 355-62.

24. Ghafourian S, Sadeghifard N, Soheili S, Sekawi Z. Extended spectrum beta-lactamases: definition, classification and epidemiology. Curr Issues Mol Biol. 2015; 17, 11-21.

25. Paterson DL, Bonomo RA. Extended-spectrum beta-lactamases: a clinical update. Clin Microbiol Rev. 2005; 18(4), $657-86$.

26. Ono HK, Satóo Y, Narita K, Naito I, Hirose S, Hisatsune J, Asano K, Hu DL, Omoe K, Sugai M, Nakane A. Identification and characterization of a novel staphylococcal emetic toxin. Appl Environ Microbiol. 2015; 81(20), 7034-40.

27. Hyeon JY, Chung GT, Bing SH, Kwon KS, Lee HH, Kim SJ, Jeon SE, Kang YH, Kim J. A foodborne outbreak of Staphylococcus aureus associated with fried chicken in Republic of Korea. J Microbiol Biotechnol. 2013; 23(1), 85-7.

28. Johler S, Weder D, Bridy C, Huguenin MC, Robert L, Hummerjohann J, Stephan R. Outbreak of staphylococcal food poisoning among children and staff at a Swiss boarding school due to soft cheese made from raw milk. J Dairy Sci. 2015; 98(5), 2944-8.

29. Dan M, Yehui W, Qingling M, Jun Q, Xingxing Z, Shuai M, Kuojun C, Jinsheng Z, Zibing C, Zaichao Z, Xuepeng C. Antimicrobial resistance, virulence gene profile and molecular typing of Staphylococcus aureus isolates from dairy cows in Xinjiang Province, northwest China. J Glob Antimicrob Resist. 2019; 16, 98-104.

30. Guo D, Liu Y, Han C, Chen Z, Ye X. Phenotypic and molecular characteristics of methicillin-resistant and methicillinsusceptible Staphylococcus aureus isolated from pigs: implication for livestock-association markers and vaccine strategies. Infect Drug Resist. 2018; 11, 1299-307.

31. Zhou Z, Zhang M, Li H, Yang H, Li X, Song X, Wang Z. Prevalence and molecular characterization of Staphylococcus aureus isolated from goats in Chongqing, China. BMC Vet Res. 2017; 13(1), 352.

32. Burns A, Shore AC, Brennan GI, Coleman DC, Egan J, Fanning S, Galligan MC, Gibbons JF, Gutierrez M, Malhotra-Kumar S, Markey BK, Sabirova JS, Wang J, Leonard FC. A longitudinal study of Staphylococcus aureus colonization in pigs in Ireland. Vet Microbiol. 2014; 174(3-4), 504-13.

33. Li T, Lu H, Wang X, Gao Q, Dai Y, Shang J, Li M. Molecular characteristics of Staphylococcus aureus causing bovine mastitis between 2014 and 2015. Front Cell Infect Microbiol. 2017; 7, 127.

34. Papadopoulos P, Papadopoulos T, Angelidis AS, Kotzamanidis C, Zdragas A, Papa A, Filioussis G, Sergelidis D. Prevalence, antimicrobial susceptibility and characterization of Staphylococcus aureus and methicillin-resistant Staphylococcus aureus isolated from dairy industries in north-central and north-eastern Greece. Int J Food Microbiol. 2019; 291, 35-41.

35. Pirolo M, Gioffrè A, Visaggio D, Gherardi M, Pavia G, Samele P, Ciambrone L, Di Natale R, Spatari G, Casalinuovo F, Visca P. Prevalence, molecular epidemiology, and antimicrobial resistance of methicillin-resistant Staphylococcus aureus from swine in southern Italy. BMC Microbiol. 2019; 19(1), 51.

36. Schwarz S, Kehrenberg C, Doublet B, Cloeckaert A. Molecular basis of bacterial resistance to chloramphenicol and florfenicol. FEMS Microbiol Rev. 2004; 28(5), 519-42.

37. Vitale M, Scatassa ML, Cardamone C, Oliveri G, Piraino C, Alduina R, Napoli C. Staphylococcal food poisoning case and molecular analysis of toxin genes in Staphylococcus aureus strains isolated from food in Sicily, Italy. Foodborne Pathog Dis. 2015; 12(1), 21-3.

38. Riva A, Borghi E, Cirasola D, Colmegna S, Borgo F, Amato E, Pontello MM, Morace G. Methicillin-resistant Staphylococcus aureus in raw milk: prevalence, SCCmec typing, enterotoxin characterization, and antimicrobial resistance patterns. J Food Prot. 2015; 78(6), 1142-6.

39. Wang D, Zhang L, Yong C, Shen M, Ali T, Shahid M, Han K, Zhou X, Han B. Relationships among superantigen toxin gene profiles, genotypes, and pathogenic characteristics of Staphylococcus aureus isolates from bovine mastitis. J Dairy Sci. 2017; 100(6), 4276-86.

40. Wu S, Huang J, Wu Q, Zhang F, Zhang J, Lei T, Chen M, Ding Y, Xue L. Prevalence and characterization of Staphylococcus aureus isolated from retail vegetables in China. Front Microbiol. 2018; 9, 1263. 
41. Clinical and Laboratory Strandards Institute. Performance standards for antimicrobial disk and dilution susceptibility tests for bacteria isolated from animals. CLSI supplement VET01-S, 3rd ed. Wayne, PA, USA; Clinical and Laboratory Strandards Institute; 2015

42. Clinical and Laboratory Strandards Institute. Performance standands for antimicrobial susceptibility testing; Twenty-fifth information supplement M100-S25. Wayne, PA, USA; Clinical and Laboratory Strandards Institute; 2015.

43. Murakami K, Minamide W, Wada K, Nakamura E, Teraoka H, Watanabe S. Identification of methicillin-resistant strains of Staphylococci by polymerase chain reaction. J Clin Microbiol. 1991; 29(10), 2240-4.

44. Stürenburg E, Kühn A, Mack D, Laufs R. A novel extended-spectrum beta-lactamase CTX-M-23 with a P167T substitution in the active-site omega loop associated with ceftazidime resistance. J Antimicrob Chemother. 2004; 54(2), 406-9.

45. Monstein HJ, Ostholm-Balkhed A, Nilsson MV, Dornbusch K, Nilsson LE. Multiplex PCR amplification assay for the detection of blaSHV, blaTEM and blaCTX-M genes in Enterobacteriaceae. APMIS. 2007; 115(12), 1400-8.

46. Chen S, Zhao S, White DG, Schroeder CM, Lu R, Yang H, McDermott PF, Ayers S, Meng J. Characterization of multipleantimicrobial-resistant Salmonella serovars isolated from retail meats. Appl Environ Microbiol. 2004; 70(1), 1-7.

47. Oliver A, Weigel LM, Rasheed JK, McGowan JE Jr, Raney P, Tenover FC. Mechanisms of decreased susceptibility to cefpodoxime in Escherichia coli. Antimicrob Agents Chemother. 2002; 46(12), 3829-36.

48. Qiao J, Zhang Q, Alali WQ, Wang J, Meng L, Xiao Y, Yang H, Chen S, Cui S, Yang B. Characterization of extended-spectrum $\beta$ lactamases (ESBLs)-producing Salmonella in retail raw chicken carcasses. Int J Food Microbiol. 2017; 248, 72-81.

49. Dallenne C, Da Costa A, Decré D, Favier C, Arlet G. Development of a set of multiplex PCR assays for the detection of genes encoding important beta-lactamases in Enterobacteriaceae. J Antimicrob Chemother. 2010; 65(5), 490-5.

50. Becker K, Roth R, Peters G. Rapid and specific detection of toxigenic Staphylococcus aureus: use of two multiplex PCR enzyme immunoassays for amplification and hybridization of staphylococcal enterotoxin genes, exfoliative toxin genes, and toxic shock syndrome toxin1 gene. J Clin Microbiol. 1998; 36(9), 2548-53.

51. Kano M, Omoe K, Shinagawa K. Multiplex PCR for comprehensive detection of staphylococcal enterotoxin. Iwate Vet. 2009; 35, 43-8. (In Japanese)

52. Omoe K, Hu DL, Takahashi-Omoe H, Nakane A, Shinagawa K. Comprehensive analysis of classical and newly described staphylococcal superantigenic toxin genes in Staphylococcus aureus isolates. FEMS Microbiol Lett. 2005; 246(2), 191-8.

53. Omoe K, Ishikawa M, Shimoda Y, Hu DL, Ueda S, Shinagawa K. Detection of seg, seh, and sei genes in Staphylococcus aureus isolates and determination of the enterotoxin productivities of $\mathrm{S}$. aureus isolates harboring seg, seh, and sei genes. $J$ Clin Microbiol. 2002; 40(3), 857-62.

54. Smyth DS, Hartigan PJ, Meaney WJ, Fitzgerald JR, Deobald CF, Bohach GA, Smyth CJ. Superantigen genes encoded by the egc cluster and SaPIbov are predominant among Staphylococcus aureus isolates from cows, goats, sheep, rabbits and poultry. J Med Microbiol. 2005; 54(Pt 4), 401-11.

\section{Tables}

Table 1 Prevalence of $S$. aureus and MRSA isolated from animals 


\begin{tabular}{llll} 
Animal & No. of samples & No. of S. aureus & No. of MRSA \\
\hline Pig (nasal swabs) & 343 & $25(7.3 \%)$ & $3(0.9 \%)$ \\
\hline Beef cattle (feces) & 165 & $1(0.6 \%)$ & 0 \\
\hline Dairy cattle (milk) & 190 & $5(2.6 \%)$ & 0 \\
\hline Goat (feces) & 88 & $10(11.4 \%)$ & 0 \\
\hline Rabbit (nasal swabs) & 105 & $16(15.2 \%)$ & 0 \\
\hline Chicken (anal swabs) & 480 & $32(6.7 \%)$ & $1(0.2 \%)$ \\
\hline Total & 1371 & $89(6.5 \%)$ & $4(0.3 \%)$
\end{tabular}

Table 2 Antimicrobial susceptibility of $S$. aureus isolated from animals to different antimicrobials 


\begin{tabular}{|c|c|c|c|c|c|c|}
\hline $\begin{array}{l}\text { Antimicrobial } \\
\text { aqents }\end{array}$ & Pig & Cattle & Goat & Rabbit & Chicken & Total \\
\hline & $\begin{array}{l}\mathrm{R}(\%) / \mathrm{S}(\%) / \mathrm{I} \\
(\%)\end{array}$ & $\begin{array}{l}\mathrm{R}(\%) / \mathrm{S}(\%) / \mathrm{I} \\
(\%)\end{array}$ & $\begin{array}{l}\mathrm{R}(\%) / \mathrm{S} \\
(\%) / \mathrm{I}(\%)\end{array}$ & $\begin{array}{l}\mathrm{R}(\%) / \mathrm{S} \\
(\%) / \mathrm{l}(\%)\end{array}$ & R (\%)/ S (\%)/I (\%) & $\begin{array}{l}\mathrm{R}(\%) / \mathrm{S}(\%) / \mathrm{I} \\
(\%)\end{array}$ \\
\hline Penicillin & $\begin{array}{l}25 \\
(100.0) / 0 / 0\end{array}$ & $6(100.0) / 0 / 0$ & $\begin{array}{l}10 \\
(100.0) / 0 / 0\end{array}$ & $\begin{array}{l}10(62.5) / 6 \\
(37.5) / 0\end{array}$ & $32(100.0) / 0 / 0$ & $\begin{array}{l}83(93.3) / 6 \\
(6.7) / 0\end{array}$ \\
\hline Ampicillin & $\begin{array}{l}25 \\
(100.0) / 0 / 0\end{array}$ & $6(100.0) / 0 / 0$ & $\begin{array}{l}10 \\
(100.0) / 0 / 0\end{array}$ & $\begin{array}{l}10(62.5) / 6 \\
(37.5) / 0\end{array}$ & $\begin{array}{l}31(96.9) / 1 \\
(3.1) / 0\end{array}$ & $\begin{array}{l}82(92.1) / 7 \\
(7.9) / 0\end{array}$ \\
\hline Cephalothin & $\begin{array}{l}1(4.0) / 20 \\
(80.0) / 4 \\
(16.0)\end{array}$ & $\begin{array}{l}0 / 5(83.3) / 1 \\
(16.7)\end{array}$ & $\begin{array}{l}1(10.0) / 9 \\
(90.0) / 0\end{array}$ & $\begin{array}{l}5(31.2) / 10 \\
(62.5) / 1(6.3)\end{array}$ & $\begin{array}{l}2(6.3) / 25 \\
(78.1) / 5(15.6)\end{array}$ & $\begin{array}{l}9(10.1) / 69 \\
(77.5) / 11 \\
(12.4)\end{array}$ \\
\hline Cefazolin & $\begin{array}{l}12(48.0) / 10 \\
(40.0) / 3 \\
(12.0)\end{array}$ & $\begin{array}{l}0 / 2(33.3) / 4 \\
(66.7)\end{array}$ & $\begin{array}{l}5(50.0) / 4 \\
(40.0) / 1 \\
(10.0)\end{array}$ & $\begin{array}{l}8(50.0) / 8 \\
(50.0) / 0\end{array}$ & $\begin{array}{l}17(53.1) / 10 \\
(31.3) / 5(15.6)\end{array}$ & $\begin{array}{l}42(47.2) / 34 \\
(38.2) / 13 \\
(14.6)\end{array}$ \\
\hline Cefoxitin & $\begin{array}{l}9(36.0) / 16 \\
(64.0) / 0\end{array}$ & $0 / 6(100.0) / 0$ & $\begin{array}{l}0 / 10 \\
(100.0) / 0\end{array}$ & $\begin{array}{l}5(31.3) / 11 \\
(68.7) / 0\end{array}$ & $\begin{array}{l}11(34.4) / 21 \\
(65.6) / 0\end{array}$ & $\begin{array}{l}25(28.1) / 64 \\
(71.9) / 0\end{array}$ \\
\hline Imipenem & $\begin{array}{l}5(20.0) / 16 \\
(64.0) / 4 \\
(16.0)\end{array}$ & $\begin{array}{l}1(16.7) / 2 \\
(33.3) / 3 \\
(50.0)\end{array}$ & $\begin{array}{l}0 / 10 \\
(100.0) / 0\end{array}$ & $\begin{array}{l}5(31.2) / 8 \\
(50.0) / 3 \\
(18.8)\end{array}$ & $\begin{array}{l}3(9.4) / 23 \\
(71.9) / 6(18.7)\end{array}$ & $\begin{array}{l}14(15.7) / 59 \\
(66.3) / 16(18.0)\end{array}$ \\
\hline Kanamycin & $\begin{array}{l}12(48.0) / 9 \\
(36.0) / 4 \\
(16.0)\end{array}$ & $\begin{array}{l}1(16.7) / 2 \\
(33.3) / 3 \\
(50.0)\end{array}$ & $\begin{array}{l}6(60.0) / 2 \\
(20.0) / 2 \\
(20.0)\end{array}$ & $\begin{array}{l}0 / 16 \\
(100.0) / 0\end{array}$ & $\begin{array}{l}12(37.5) / 13 \\
(40.6) / 7(21.9)\end{array}$ & $\begin{array}{l}31(34.8) / 42 \\
(47.2) / 16 \\
(18.0)\end{array}$ \\
\hline Gentamicin & $\begin{array}{l}8(32.0) / 14 \\
(56.0) / 3 \\
(12.0)\end{array}$ & $\begin{array}{l}0 / 5(83.3) / 1 \\
(16.7)\end{array}$ & $\begin{array}{l}0 / 9 \\
(90.0) / 1 \\
(10.0)\end{array}$ & $\begin{array}{l}0 / 16 \\
(100.0) / 0\end{array}$ & $\begin{array}{l}3(9.4) / 27 \\
(84.4) / 2(6.2)\end{array}$ & $\begin{array}{c}11(12.4) / 71 \\
(79.8) / 7(7.8)\end{array}$ \\
\hline Amikacin & $\begin{array}{l}0 / 24(96.0) / 1 \\
(4.0)\end{array}$ & $0 / 6(100.0) / 0$ & $\begin{array}{l}1(10.0) / 8 \\
(80.0) / 1 \\
(10.0)\end{array}$ & $\begin{array}{l}0 / 16 \\
(100.0) / 0\end{array}$ & $\begin{array}{l}3(9.4) / 25 \\
(78.1) / 4(12.5)\end{array}$ & $\begin{array}{l}4(4.5) / 79 \\
(88.8) / 6(6.7)\end{array}$ \\
\hline Tobramycin & $\begin{array}{l}11(44.0) / 11 \\
(44.0) / 3 \\
(12.0)\end{array}$ & $\begin{array}{l}1(16.7) / 5 \\
(83.3) / 0\end{array}$ & $\begin{array}{l}5(50.0) / 5 \\
(50.0) / 0\end{array}$ & $\begin{array}{l}0 / 16 \\
(100.0) / 0\end{array}$ & $\begin{array}{l}10(31.2) / 22 \\
(68.8) / 0\end{array}$ & $\begin{array}{l}27(30.3) / 59 \\
(66.3) / 3(3.4)\end{array}$ \\
\hline Erythromycin & $\begin{array}{l}14(56.0) / 2 \\
(8.0) / 9(36.0)\end{array}$ & $\begin{array}{l}1(16.7) / 0 / 5 \\
(83.3)\end{array}$ & $\begin{array}{l}3 \\
(30.0) / 0 / 7 \\
(70.0)\end{array}$ & $\begin{array}{l}7(43.7) / 4 \\
(25.0) / 5 \\
(31.3)\end{array}$ & $\begin{array}{l}12(37.5) / 2 \\
(6.2) / 18(56.3)\end{array}$ & $\begin{array}{l}37(41.6) / 7 \\
(7.9) / 45(50.5)\end{array}$ \\
\hline Azithromycin & $\begin{array}{l}15(60.0) / 8 \\
(32.0) / 2(8.0)\end{array}$ & $\begin{array}{l}2(33.3) / 4 \\
(66.7) / 0\end{array}$ & $\begin{array}{l}3(30.0) / 4 \\
(40.0) / 3 \\
(30.0)\end{array}$ & $\begin{array}{l}3(18.7) / 12 \\
(75.0) / 1 \\
6.3)\end{array}$ & $\begin{array}{l}13(40.6) / 9 \\
(28.1) / 10(31.3)\end{array}$ & $\begin{array}{l}36(40.4) / 37 \\
(41.6) / 16 \\
(18.0)\end{array}$ \\
\hline Clarithromycin & $\begin{array}{l}12(48.0) / 12 \\
(48.0) / 1(4.0)\end{array}$ & $\begin{array}{l}2(33.3) / 3 \\
(50.0) / 1(16.7)\end{array}$ & $\begin{array}{l}2(20.0) / 6 \\
(60.0) / 2 \\
(20.0)\end{array}$ & $\begin{array}{l}5(31.2) / 9 \\
(56.2) / 2 \\
(12.6)\end{array}$ & $\begin{array}{l}14(43.7) / 13 \\
(40.6) / 5(15.7)\end{array}$ & $\begin{array}{l}35(39.3) / 43 \\
(48.3) / 11 \\
(12.4)\end{array}$ \\
\hline Tetracycline & $\begin{array}{l}14(56.0) / 4 \\
(16.0) / 7 \\
(28.0)\end{array}$ & $\begin{array}{l}1(16.7) / 1 \\
(16.7) / 4 \\
(66.6)\end{array}$ & $\begin{array}{l}7 \\
(70.0) / 0 / 3 \\
(30.0)\end{array}$ & $\begin{array}{l}8(50.0) / 7 \\
(43.7) / 1 \\
(6.3)\end{array}$ & $\begin{array}{l}21 \\
(65.6) / 6(18.8) / 5 \\
(15.6)\end{array}$ & $\begin{array}{l}51(57.3) / 18 \\
(20.2) / 20 \\
(22.5)\end{array}$ \\
\hline Doxycycline & $\begin{array}{l}15(60.0) / 10 \\
(40.0) / 0\end{array}$ & $\begin{array}{l}1(16.7) / 5 \\
(83.3) / 0\end{array}$ & $\begin{array}{l}5(50.0) / 3 \\
(30.0) / 2 \\
(20.0)\end{array}$ & $\begin{array}{l}0 / 9(56.3) / 7 \\
(43.7)\end{array}$ & $\begin{array}{c}19(59.4) / 11 \\
(34.4) / 2(6.2)\end{array}$ & $\begin{array}{l}40(44.9) / 38 \\
(42.7) / 11 \\
(12.4)\end{array}$ \\
\hline Chloramphenicol & $\begin{array}{l}13(52.0) / 8 \\
(32.0) / 4 \\
(16.0)\end{array}$ & $\begin{array}{l}0 / 3(50.0) / 3 \\
(50.0)\end{array}$ & $\begin{array}{l}2(20.0) / 4 \\
(40.0) / 4 \\
(40.0)\end{array}$ & $\begin{array}{l}0 / 15 \\
(93.8) / 1 \\
(6.2)\end{array}$ & $\begin{array}{l}13(40.6) / 10 \\
(31.2) / 9(28.2)\end{array}$ & $\begin{array}{l}28(31.5) / 40 \\
(44.9) / 21 \\
(23.6)\end{array}$ \\
\hline Clindamycin & $\begin{array}{l}15 \\
(60.0) / 0 / 10 \\
(40.0)\end{array}$ & $\begin{array}{l}1(16.7) / 1 \\
(16.7) / 4 \\
(66.6)\end{array}$ & $\begin{array}{l}0 / 0 / 10 \\
(100.0)\end{array}$ & $\begin{array}{l}5(31.3) / 9 \\
(56.2) / 2 \\
(12.5)\end{array}$ & $\begin{array}{l}13(40.6) / 1 \\
(3.1) / 18(56.3)\end{array}$ & $\begin{array}{l}34(38.2) / 11 \\
(12.4) / 44 \\
(49 . .4)\end{array}$ \\
\hline Norfloxacin & $13(52.0) / 12$ & $1(16.7) / 4$ & $\begin{array}{l}0 / 8 \\
\text { Page 12/15 }\end{array}$ & $0 / 16$ & $10(31.3) / 21$ & $24(27.0) / 61$ \\
\hline
\end{tabular}




\begin{tabular}{|c|c|c|c|c|c|c|}
\hline & $(48.0) / 0$ & $\begin{array}{l}(66.7) / 1 \\
(16.6)\end{array}$ & $\begin{array}{l}(80.0) / 2 \\
(20.0)\end{array}$ & $(100.0) / 0$ & $(65.6) / 1(3.1)$ & $(68.5) / 4(4.5)$ \\
\hline Ciprofloxacin & $\begin{array}{l}12(48.0) / 11 \\
(44.0) / 2(8.0)\end{array}$ & $\begin{array}{l}1(16.7) / 4 \\
(66.7) / 1 \\
(16.6)\end{array}$ & $\begin{array}{l}2(20.0) / 4 \\
(40.0) / 4 \\
(40.0)\end{array}$ & $\begin{array}{l}0 / 16 \\
(100.0) / 0\end{array}$ & $\begin{array}{l}11 \\
(34.4) / 12(37.5) / 9 \\
(28.1)\end{array}$ & $\begin{array}{l}26(29.2) / 47 \\
(52.8) / 16 \\
(18.0)\end{array}$ \\
\hline Enrofloxacin & $\begin{array}{l}13(52.0) / 12 \\
(48.0) / 0\end{array}$ & $\begin{array}{l}0 / 3(50.0) / 3 \\
(50.0)\end{array}$ & $\begin{array}{l}0 / 6 \\
(60.0) / 4 \\
(40.0)\end{array}$ & $\begin{array}{l}0 / 14 \\
(87.5) / 2 \\
(12.5)\end{array}$ & $\begin{array}{l}11(34.4) / 10 \\
(31.2) / 11(34.4)\end{array}$ & $\begin{array}{l}24(27.0) / 45 \\
(50.5) / 20 \\
(22.5)\end{array}$ \\
\hline Ofloxacin & $\begin{array}{l}4(16.0) / 15 \\
(60.0) / 6(24.0)\end{array}$ & $0 / 6(100.0) / 0$ & $\begin{array}{l}1(10.0) / 8 \\
(80.0) / 1 \\
(10.0)\end{array}$ & $\begin{array}{l}0 / 16 \\
(100.0) / 0\end{array}$ & $\begin{array}{l}3(9.4) / 22 \\
(68.7) / 7(21.9)\end{array}$ & $\begin{array}{l}8(9.0) / 67 \\
(75.3) / 14 \\
(15.7)\end{array}$ \\
\hline Enoxacin & $\begin{array}{l}12(48.0) / 12 \\
(48.0) / 1(4.0)\end{array}$ & $\begin{array}{l}1(16.7) / 5 \\
(83.3) / 0\end{array}$ & $\begin{array}{l}0 / 10 \\
(100.0) / 0\end{array}$ & $\begin{array}{l}0 / 16 \\
(100.0) / 0\end{array}$ & $\begin{array}{l}10(31.3) / 21 \\
(65.6) / 1(3.1)\end{array}$ & $\begin{array}{l}23(25.8) / 64 \\
(71.9) / 2(2.3)\end{array}$ \\
\hline $\begin{array}{l}\text { Trimethprim- } \\
\text { sulfamethoxazole }\end{array}$ & $\begin{array}{l}11(44.0) / 13 \\
(52.0) / 1(4.0)\end{array}$ & $\begin{array}{l}1(16.7) / 5 \\
(83.3) / 0\end{array}$ & $\begin{array}{l}0 / 8 \\
(80.0) / 2 \\
(20.0)\end{array}$ & $\begin{array}{l}2(12.5) / 14 \\
(87.5) / 0\end{array}$ & $\begin{array}{l}4(12.5) / 25 \\
(78.1) / 3(9.4)\end{array}$ & $\begin{array}{l}18(20.2) / 65 \\
(73.0) / 6(6.8)\end{array}$ \\
\hline Trimethprim & $\begin{array}{l}13(52.0) / 11 \\
(44.0) / 1(4.0)\end{array}$ & $\begin{array}{l}1(16.7) / 5 \\
(83.3) / 0\end{array}$ & $\begin{array}{l}1(10.0) / 9 \\
(90.0) / 0\end{array}$ & $\begin{array}{l}3(18.8) / 13 \\
(81.2) / 0\end{array}$ & $\begin{array}{l}7(21.9) / 22 \\
(68.8) / 3(9.3)\end{array}$ & $\begin{array}{l}25(28.1) / 60 \\
(67.4) / 4(4.5)\end{array}$ \\
\hline
\end{tabular}

Table 3 Resistant pattern and MDR of $S$. aureus isolates

\begin{tabular}{lllllll} 
Resistant pattern & Pig (\%) & Cattle (\%) & Goat (\%) & Rabbit (\%) & Chicken (\%) & Total (\%) \\
\hline 1 & $1(4.0)$ & $1(16.7)$ & $3(30.0)$ & $5(31.3)$ & $1(3.1)$ & $11(12.3)$ \\
\hline 2 & $5(20.0)$ & $2(33.3)$ & 0 & $1(6.3)$ & $4(12.5)$ & $12(13.5)$ \\
\hline 3 & $2(8.0)$ & $2(33.3)$ & 0 & $3(18.7)$ & $4(12.5)$ & $11(12.3)$ \\
\hline 4 & $3(12.0)$ & 0 & 0 & $3(18.7)$ & $4(12.5)$ & $10(11.2)$ \\
\hline 5 & $1(4.0)$ & $1(16.7)$ & $5(50.0)$ & $3(18.7)$ & $5(15.6)$ & $15(16.9)$ \\
\hline 6 & 0 & 0 & $2(20.0)$ & $1(6.3)$ & $5(15.6)$ & $8(9.0)$ \\
\hline 7 & $2(8.0)$ & 0 & 0 & 0 & $7(22.0)$ & $9(10.1)$ \\
\hline 8 & $2(8.0)$ & 0 & 0 & 0 & $1(3.1)$ & $3(3.4)$ \\
\hline 9 & $6(24.0)$ & 0 & 0 & 0 & $1(3.1)$ & $7(7.9)$ \\
\hline 10 & $3(12.0)$ & 0 & 0 & 0 & 0 & $3(3.4)$ \\
\hline Total & 25 & 6 & 10 & 16 & 32 & 89
\end{tabular}

Table 4 Prevalence of staphylococcal toxin genes in $S$. aureus isolates 


\begin{tabular}{lllllll} 
Toxin gene & Pig (\%) & Cattle $(\%)$ & Goat (\%) & Rabbit (\%) & Chicken (\%) & Total (\%) \\
\hline sea & 0 & $2(33.3)$ & 0 & 0 & $2(6.3)$ & $4(4.5)$ \\
\hline seb & 0 & $1(16.7)$ & 0 & 0 & $4(12.5)$ & $5(5.6)$ \\
\hline sec & $6(24.0)$ & $1(16.7)$ & 0 & $1(6.3)$ & $13(40.6)$ & $21(23.4)$ \\
\hline sed & $2(8.0)$ & 0 & $2(20.0)$ & 0 & $5(15.6)$ & $9(10.1)$ \\
\hline see & 0 & $1(16.7)$ & 0 & 0 & 0 & $1(1.1)$ \\
\hline seg & $13(52.0)$ & $1(16.7)$ & $4(40.0)$ & $12(75.0)$ & $16(50.0)$ & $46(51.7)$ \\
\hline seh & 0 & $1(16.7)$ & 0 & $11(68.8)$ & $1(3.1)$ & $13(14.6)$ \\
\hline sei & $9(36.0)$ & $3(50.0)$ & $6(60.0)$ & $14(87.5)$ & $20(62.5)$ & $52(58.4)$ \\
\hline selj & $14(56.0)$ & $2(33.3)$ & $5(50.0)$ & $5(31.3)$ & $9(28.1)$ & $35(39.3)$ \\
\hline sek & $11(44.0)$ & $1(16.7)$ & $4(40.0)$ & 0 & $13(40.6)$ & $29(32.6)$ \\
\hline sel & $9(36.0)$ & $3(50.0)$ & $3(30.0)$ & $8(50.0)$ & $1(3.1)$ & $24(27.0)$ \\
\hline sem & $6(24.0)$ & $2(33.3)$ & $3(30.0)$ & $2(12.5)$ & $19(59.4)$ & $32(36.0)$ \\
\hline sen & $10(40.0)$ & $1(16.7)$ & $1(10.0)$ & 0 & $7(21.9)$ & $19(21.3)$ \\
\hline seo & $15(60.0)$ & $2(33.3)$ & $3(30.0)$ & $1(6.3)$ & $13(40.6)$ & $34(38.2)$ \\
\hline sep & $11(44.0)$ & $1(16.7)$ & $4(40.0)$ & 0 & $13(40.6)$ & $29(32.6)$ \\
\hline seq & 0 & 0 & 0 & 0 & 0 & 0 \\
\hline ser & $11(44.0)$ & $1(16.7)$ & 0 & 0 & 0 & $12(13.5)$ \\
\hline ses & $2(8.0)$ & 0 & $2(20.0)$ & $6(37.5)$ & $1(3.1)$ & $11(12.4)$ \\
\hline set & $1(4.0)$ & 0 & 0 & $7(43.8)$ & $2(6.3)$ & $10(11.2)$ \\
\hline tst-1 & $11(44.0)$ & $6(100.0)$ & $5(50.0)$ & $10(62.5)$ & $18(56.3)$ & $50(56.2)$ \\
\hline
\end{tabular}

Table 5 Staphylococcal toxin gene pattern of $S$. aureus isolates

\begin{tabular}{lllllll} 
Toxin gene pattern & Pig & Cattle & Goat & Rabbit & Chicken & Total \\
\hline 1 & 2 & & & 1 & 1 & 4 \\
\hline 2 & 1 & 1 & 1 & & 5 & 8 \\
\hline 3 & 5 & 4 & 1 & 1 & 2 & 13 \\
\hline 4 & 4 & 1 & 2 & 4 & 7 & 18 \\
\hline 5 & 4 & 1 & & 3 & 4 & 12 \\
\hline 6 & 1 & 1 & 1 & 1 & 5 & 9 \\
\hline 7 & 1 & 2 & & 4 & 8 & 15 \\
\hline 8 & 4 & & & 1 & & 5 \\
\hline 9 & 2 & & 1 & & & 3 \\
\hline 10 & 1 & & & & & 1
\end{tabular}


This is a list of supplementary files associated with this preprint. Click to download.

- TableS3.docx

- Tables1.docx

- Tables2.docx 